\title{
COVID-19 Pandemic: health professionals' perception about the assistance mentioned in television media
}

\author{
Pandemia da COVID-19: percepção dos profissionais de saúde sobre a assistência aludida em mídia televisiva \\ Pandemia de COVID-19: percepción de los profesionales de salud sobre la asistencia aludida en medio televisivo
}

Erika Fernanda dos Santos Bezerra Ludwig' ORCID: 0000-0003-3048-9356

Nathalia Vasconcelos Fracasso' ORCID: 0000-0001-7424-9771

Renata Pires de Arruda Faggion' ORCID: 0000-0001-6596-4693

Stephanye Vithória Martins da Silva' ORCID: 0000-0002-9278-6279

Larissa Gutierrez de Carvalho Silva' ORCID: 0000-0003-0209-930X

Maria do Carmo Fernandez Lourenço Haddad' ORCID: 0000-0001-7564-8563

'Universidade Estadual de Londrina. Londrina, Paraná, Brazil.

How to cite this article: Ludwig EFSB, Fracasso NV, Faggion RPA, Silva SVM, Silva LGC, Haddad MCFL. COVID19 Pandemic: health professionals' perception about the assistance mentioned in television media. Rev Bras Enferm. 2021;74(Suppl 1):e20201258. https://doi.org/10.1590/0034-7167-2020-1258

Corresponding author: Erika Fernanda dos Santos Bezerra Ludwig E-mail: erikaf.ludwig@gmail.com

EDITOR IN CHIEF: Dulce Barbosa ASSOCIATE EDITOR: Maria Itayra Padilha

Submission: $12-03-2020$

Approval: 01-20-2021

\section{ABSTRACT}

Objective: Exhibit the health professionals' perception about the assistance provided during the COVID-19 pandemic mentioned television media. Methods: Qualitative study developed after analysis of the videos with a testimonial from practitioners assisting patients with COVID-19, presented by the series "Inside Here" (in Portuguese, "Aqui Dentro"), of Globo TV News Jornal Nacional, broadcasted in 2020. Textual data was processed by the software IRAMUTEQ with descending hierarchical classification and content analysis, having the theoretical framework as the psychodynamics of Dejours' study. Results: Three categories emerged: work overload in assisting; subjective mobilization of health professionals; strategies to face in assisting. Final considerations: We verified the physical and psychic work overload during the assistance, but there was a concern to ensure a humanized care. Despite the difficulties faced, the recovery and discharge from patients generated motivation and satisfaction in front of the COVID-19 scenario.

Descriptors: Pandemic; COVID-19; Health Professionals; Health Assistance; Television.

\section{RESUMO}

Objetivo: Desvelar a percepção dos profissionais de saúde sobre a assistência prestada durante a pandemia da COVID-19, aludida em mídia televisiva. Métodos: Estudo qualitativo desenvolvido após análise de vídeos com depoimentos de profissionais atuantes na assistência a pacientes com COVID-19, apresentados pelo quadro "Aqui dentro", do Jornal Nacional da Rede Globo de Televisão, transmitidos em 2020. Os dados textuais foram processados pelo software IRAMUTEQ com classificação hierárquica descendente e análise de conteúdo, sendo o referencial teórico, a psicodinâmica do trabalho de Dejours. Resultados: Emergiram três categorias: Sobrecarga de trabalho na prestação da assistência; Mobilização subjetiva dos profissionais de saúde; Estratégias para enfrentamento na prestação da assistência. Considerações finais: Verificou-se a sobrecarga de trabalho físico e psíquico durante a assistência, mas com preocupação em garantir cuidado humanizado. Apesar das dificuldades enfrentadas, a recuperação e alta dos pacientes geraram motivação e satisfação diante do cenário da COVID-19.

Descritores: Pandemia; COVID-19; Profissionais de Saúde; Assistência à Saúde; Televisão.

\section{RESUMEN}

Objetivo: Desvelar la percepción de profesionales de salud sobre la asistencia prestada durante la pandemia de COVID-19, aludida en medio televisivo. Métodos: Estudio cualitativo desarrollado después de análisis de vídeos con deposiciones de profesionales actuantes en la asistencia a pacientes con COVID-19, presentados por el cuadro "Aquí dentro", del Periódico Nacional de la Rede Globo de Televisión, transmitidos en 2020. Datos textuales fueron procesados por software IRAMUTEQ con clasificación jerárquica descendente y análisis de contenido, siendo el referencial teórico, la psicodinámica del trabajo de Dejours. Resultados: Emergieron tres categorías: Sobrecarga de trabajo en prestación de asistencia; Movilización subjetiva de profesionales de salud; Estrategias para enfrentamiento en prestación de asistencia. Consideraciones finales: Verificó la sobrecarga de trabajo físico y psíquico durante la asistencia, pero con preocupación en garantizar cuidado humanizado. Aunque las dificultades enfrentadas, la recuperación y alta de los pacientes generaron motivación y satisfacción frente al escenario de COVID19.

Descriptores: Pandemia; COVID-19; Profesionales de Salud; Asistencia a la Salud; Televisión. 


\section{INTRODUCTION}

The emergency of the new severe acute respiratory syndrome caused by the virus Coronavirus 2 (SARS-CoV-2) started in Wuhan, China, in December 2019 ${ }^{(1-2)}$. In Brazil, confirmation of the first COVID-19 case was in São Paulo, on February 25, 2020, however, only on March 11, the World Health Organization (WHO) classified the disease world outbreak as a pandemic ${ }^{(3)}$.

Seven months later, on September 19, 2020, 4,717.991 cases and 141,406 deaths by COVID-19(4) ${ }^{(4)}$ were confirmed in Brazil, corresponding to the biggest problem in public health of the last hundred years ${ }^{(5)}$.

The impacts in public health due to a virus of easy and fast spread in the population led to a sudden change in the routine of health services, intensifying hospital admissions for respiratory complications, with consequent influence on the health of the care teams, due to the contamination and illness of the practitioners involved in the care of patients ${ }^{(6)}$.

Therefore, some prevention and control strategies were taken such as the use of fabric masks of two layers, construction of field hospitals, hiring more professionals ${ }^{(7)}$. Also, they implement social distancing, and reinforced the hygiene measures, to decrease the numbers of victims of COVID-19 and avoid a collapse in health services $^{(8)}$.

Strategies to prevent a panic scenario or inappropriate behavior were clearly announced by the media to the population and to health professionals, contributing to coping with the disease. Therefore, several investments were made to promote health education and socialize contents related to disease and health issues ${ }^{(9)}$.

Media was the ultimate tool for the socialization of information, as it can reach different audiences through newspapers, TV programs, magazines, and social media. Its contribution is essential to inform about the pandemic advance, including data referred to healed percentual, and number of deaths, latest researches, and health services reorganization, and other subjects ${ }^{(10)}$.

Together with the socialization of information, media highlighted the importance of health professionals. These practitioners are exposed to a new work condition, extremely risked, and their presence becomes paramount to ensure the essential care to patients with the COVID-19 virus(6).

Scientific literature highlights the overcrowding in the health institutions, lack of beds for hospitalization, and care equipment, as well as the main issues for the health professionals in the pandemic ${ }^{(6,11)}$. We emphasize the importance of the labor activity for the analysis of the men and their relationship with the material and the psychic world because they seek to satisfy their needs through their activities, such as seek pleasure and avoid suffering ${ }^{(12)}$.

Before this scenario, which includes the rapid population involvement and the importance of healthcare for them, we ask: What is the perception of health professionals about the assistance provided during the COVID-19 pandemic, mentioned in the television media?

Lastly, we highlight that the descriptive study allows us to fill the scientific gaps regarding the theme, contributing to the construction of actions that promote the improvement of the health conditions to this population group.

\section{OBJECTIVE}

Exhibit the perception of health professionals about the healthcare provided during the COVID-19 pandemic, mentioned in television media.

\section{METHODS}

\section{Ethical aspects}

The study complied with the ethical and legal principles governing scientific research advocated in Resolution No. 466/2012 of the National Health Council. As it does not directly include human beings, since data were collected by electronic means of public access (free), it was not registered or evaluated by the Research Ethics Committee, following the determination of the Resolution No. 510 of April 7, 2016, in the terms of the Act No. 12.527/2011.

\section{Theoretical Framework}

Study based on the theoretical framework of the psychodynamics of work proposed by Dejours, who dedicates to the dynamic analysis of psychic processes involved in confronting the person with the reality of work ${ }^{(13)}$. It seeks to correlate the subjective aspects of the individual with the work, as human relations in institutions are influenced by the way the work is organized ${ }^{(14)}$.

\section{Type of study}

This is an exploratory and descriptive, documentary, qualitative study, with the sample characterization, based on Bardin's content analysis. We used the instrument Consolidated Criteria for Reporting Qualitative Research (COREQ) as a guide of the method.

\section{Study setting}

The survey was developed using testimonials of health professionals assisting patients with COVID-19, broadcasted by the series "Inside Here," of Globo TV News Jornal Nacional, broadcasted primetime every night. The TV channel is nationally broadcasted and is part of the "great press" and has been a record holder in the country since the $1960 \mathrm{~s}^{(15)}$.

\section{Data source}

The series "Inside Here" was created in May 2020, during the COVID-19 pandemic to present videos containing testimonials of the health professionals who shared their experiences and feelings while assisted patients with COVID-19, on-air from Monday to Friday.

All testimonials exhibited by the television media between May 11, 220 (premiere series) until August 11, 2020, were included in this survey. Each testimonial lasted an average of one minute.

\section{Collection and organization of data}

The collection of data was carried out through the cataloging of the testimonials published by the referred series, with the 
professionals' profile drawn with the selection of the variables gender, profession, place, and State where they work. Textual corpus (gathering of the materials to be analyzed in a single document) was generated based on the transcription of the professionals' speeches and identified by the word "Video," followed by a sequential number ${ }^{(16)}$.

\section{Data Analysis}

Data obtained after the transcription was stored and analyzed through the software IRAMUTEQ (Interface de R pour les Analyses Multidimensionnelles de Textes et de Questionnaires), We used the Descending Hierarchical Classification (DHC), which consists of grouping the words in classes, having each class similar to each other and, at the same time, different from other classes. Thus, the text segments are classified according to the respective vocabularies $^{(16-17)}$.

Based on the contents of the testimonials and DHC generated by the IRAMUTEQ, we elaborated the analysis categories, following the steps proposed by Bardin's thematic content analysis technique $^{(18)}$. Therefore, the videos were pre-analyzed by transcribing the testimonials. Then, we explored the material, looking for the thematic cut, and then interpreted the results to improve the understanding of the analysis categories for discussion.

\section{RESULTS}

The sample had 66 videos with testimonials from health professionals who assist patients with COVID-19, presented in television media, which are characterized in Table 1.

Regarding the analysis performed by the IRAMUTEQ, we found 7,222 occurrences of words, 973 active forms, being analyzed 199 text segments by the software, with $91 \%$ retention in the Descending Hierarchical Classification (DHC) (Figure 1).

The DHC divided the corpus into seven classes. Based on the organization, analysis, and content of the videos' transcriptions, categories were shown as the work overload in assistance, the subjective mobilization of the health professionals, and strategies for coping with adverse situations in assistance. It is relevant to highlight that each category was built through the frequency of words listed by professionals according to DHC.

\section{Work overload in assistance}

Among health professionals, we noticed that the work overload experienced to assist patients with COVID-19. They expressed in their testimonials: an excessive amount of tasks, work under pressure, and demands imposed by the new workflow, and overvaluation of technical skills in labor-management of people and materials - which relate to the words listed in Classes 2, 3, 4, and 5 .
Table 1 - Characterization of health professionals assisting patients with COVID-19, according to gender, professional category, place, sector, and State $-(n=66)$, Brazil, 2020

\begin{tabular}{lcc}
\hline Variable & $\mathbf{n}$ & $\%$ \\
\hline Gender & & \\
Men & 21 & 32 \\
Women & 45 & 68 \\
Professional category & & \\
$\quad$ Physicians & 28 & 42.4 \\
Nurses & 23 & 35 \\
Physiotherapist & 5 & 7.6 \\
Speech Therapist & 2 & 3 \\
*Other categories & 8 & 12 \\
Workplace & & \\
$\quad$ Hospitals & 65 & 98.4 \\
Clinics & 1 & 1.6 \\
Sector of activity & & \\
Intensive Care Unit & 9 & 14 \\
Emergency Room & 4 & 6 \\
Maternity & 3 & 5 \\
No description & 49 & 75 \\
State of activity & & \\
Rio de Janeiro & 15 & 23 \\
Sao Paulo & 8 & 12 \\
Paraiba & 5 & 7 \\
Ceara & 4 & 6 \\
Bahia & 3 & 4 \\
**Other States & 20 & 30 \\
\hline
\end{tabular}

Notes: *Correspond to hospital administrator, cleaning assistant, dentist, makeup artist, music therapist, nutritionist, psychologist and nursing technician, one (1.5\%) of each. **States of Minas Gerais, Tocantins, Espirito Santo, Rio Grande do Sul, Para, Rio Grande do Norte, Parana, Roraima, Santa Catarina, Sergipe e Distrito Federal, two (3\%) of each. In addition, six (9\%) worked in the States of Mato Grosso, Mato Grosso do Sul, Acre, Rondonia, Maranhao, and Amazonas, with one $(1.5 \%)$ practitioner of each State. We emphasize that one of the videos did not bring the information of the State where the practitioner worked.

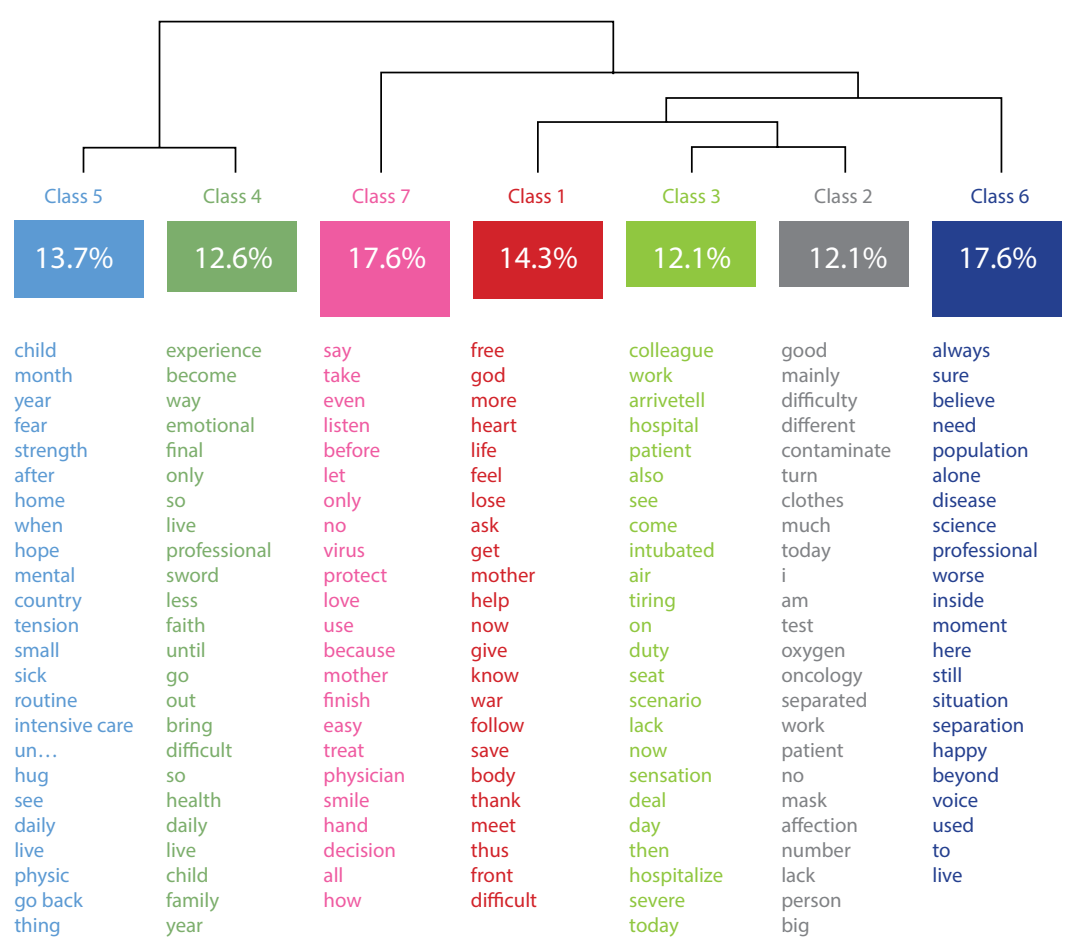

Figure 1 - Descending Hierarchical Classification Dendrogram of the textual corpus of the practitioners, Londrina, Parana, Brazil, 2020 
We are working with an overcrowding of more than double, the work overload is very high because of sick leave, the people who got coronavirus. (Video 2 - Nurse)

And we see a complete chaos: we have crowded hospitals, colleagues getting sick, colleagues being in serious condition due to the new coronavirus. (Video 7 - Physician)

Our difficulties here during the pandemic are great. The lack of personal protective equipment, training, a clear conversation with the practitioners. (Video 6 - Nurse)

It is not easy to wear the mask during 11 hours of duty in the hospital. It's not easy for you to wear gloves for all procedures, and we behind all this personal protective equipment. (Video 12 - Nurse)

The result of workload is determined by several factors and elements that are part of labor condition, but it is also influenced by the environment ${ }^{(13)}$. It is confirmed by the practitioners of Classes 2 and 6 who recognize that people's behavior in the external environment interferes with assistance.

I was once asked if was furious after an exhausting day at work and found people without a mask on the street. (Video 25 - Physician)

I realize that the population, part of it, still neglects this disease that has been killing us all the time. People go out without a mask, crowd, party, and we professionals have to give up our home, our family to be here daily. (Video 40 - Nurse)

\section{Subjective mobilization of health professionals}

We observed that the subjective mobilization is revealed by feelings and sensations of suffering and pleasure of the health professionals in assisting patients during the COVID-19 pandemic because of the high degree of virus contagion besides changes and restrictions imposed in the care flow of health institutions.

I'm exhausted. It is physical, mental and emotional tiredness. (Video 65 - Physician)

Many colleagues speak and report at the end of the shift the tiredness they are having, their sleeping difficulties, the strong scenes of patients who die and who cannot do anything, due to the patient's severity. (Video 10 - Nurse)

The feeling we have is that the body cannot take it anymore; we really want to help but, at the same time, we want to ask for help and go home together with our family. (Video 56 - Nurse)

And the fear of taking the virus home is daily. So, when I look at my son, when I try to kiss him, I say: "I can't do this, because I can't contaminate you." (Video 4 - Physician)

A co-worker of ours contracted the virus and couldn't take it: she ended up dying last week, and that brings a great sadness, a fear. (Video 5 - Nursing Technician)

We feel anguished to see the patients who come here. The mothers giving birth alone, the fathers and the family trying to see the baby. (Video 6 - nurse)
That moment, which was a moment of joy, happiness, became a moment of sadness, anguish and uncertainty. The hug at the end of childbirth, today can no longer be given. (Video 30 - Physician)

In addition to the feelings of fear, sadness, and tiredness expressed by the practitioners, it was also evident, through the data generated by the IRAMUTEQ in Class 7 of DHC, for the frequency of spoken words that reflect feelings of concern of the professionals in guaranteeing humanization in the assistance provided.

We cannot lose our humanization in treating a patient, because that patient is also suffering from isolation. (Video 12 - Nurse)

It means reframing our contact with patients through other tools, it is smiling with a look, welcoming with a masked smile. (Video 23 - Physician)

That moment of duty that you can best show your empathy, your security, the respect and affection for that patient, for that family. (Video 13 - Physician)

For those practitioners, who work in the pandemic scenario, reaching humanization becomes a concern and a challenge, to bring a relief of feelings that are experienced during the hospitalization; thus, there is an intention to transmit safety, welcoming, and satisfaction in assistance.

\section{Coping strategies in assistance}

Actions and feelings of practitioners when coping with adverse situations to endure the work and the suffering and achieve working pleasure were evident and, thus, they remain active in assisting patients. It is related to the word listed in Class 1 of DHC (Graça, Ajudar, Guerra e Salvar), as per identified in testimonials:

We have a mission. We are there to save someone's love, someone has to leave, someone needs a bed, someone is waiting. And this is what motivates us, every day. (Video 20 - Physiotherapist)

But the war continues, and there are many people who will need me, and I will return as strong as possible to help those who need it most. (Video 17 - Physiotherapist)

We feel a great joy, because there is nothing more pleasurable than helping someone who needs your help. (Video 32 - Speech Therapist)

A job must play an important role in the subject's life for the psychic construction and maintenance of each individual, being the lever to transform situations of suffering into pleasure ${ }^{(19)}$. Practitioners show a motivation to help in patients' recovery since they recognize that patients need assistance and they also feel satisfied in this activity, which is maximized during the recovery, discharge, and cure of patients.

And one of the things that most magnifies us and gives us happiness and pleasure is seeing a discharge, a patient who came with shortness of breath to be restored after oxygen, and, in a few days, you will see him return home. (Video 2 - Nurse) 


\section{DISCUSSION}

Health systems worked at their maximum capacity all over the world. However, the scenario of the COVID-19 pandemic exposes an insufficient number of human resources in health, a lack of skilled professionals, and few internal prevention actions in assisting spaces, in addition to other actions need to cope with public health emergencies ${ }^{(11)}$.

There is a concern regarding the capacity and possible collapse of the health system, absence of effective and safe treatment interventions, such as vaccines or drugs ${ }^{(20)}$, as well as a high number of people who need hospitalization ${ }^{(21)}$. The study confirms that equipment can be manufactured with urgency or operated $100 \%$ for long periods, differently from health professionals ${ }^{(11)}$.

For the psychodynamics of work, the lack of personnel generates suffering, since the excess of work needs to be shared among the available workers; and the "workloads" are defined as a set of efforts developed for the requirements of the tasks - a concept that encompasses physical, cognitive, and psycho-affective (emotional) efforts. There is a correlation between the type of efforts, i.e., the overload in one of them may reflect in overload of the others ${ }^{(13)}$.

In Brazil, the Single Health System (SUS) is one of the biggest and more complex public health systems in the world and has been providing the necessary base for the action of coping $\mathrm{CO}$ VID-19(22). However, it had already shown limitations, before the COVID-19 pandemic, experienced by health professionals, such as investment reduction, and instability, which were evidenced by the pandemic scenario ${ }^{(23)}$.

The lack of PPE and the work overload are crucial factors that increase the risk of infection by SARS-COV-2 by these practitioners ${ }^{(24)}$. According to Dejours ${ }^{(13)}$, these elements become necessary for the worker to improvise during the work, having to break rules and take risks. The scientific literature shows that health professionals have three times more chances to contract the virus than the general population ${ }^{(23)}$, and, according to reports, the prevalence of COVID-19 is higher than $10 \%$ in this population in many countries, reaching $20 \%$ among the Italians ${ }^{(11)}$.

Mortality due to COVID-19 among health professionals was high in studies conducted in several countries, mainly among physicians and nurses, predominantly female, a classification that corresponds to the sample of practitioners who participate in the present study ${ }^{(24-26)}$.

Such reality is depicted in the perception of the practitioners and confirmed in this study, when they emphasize their concern with the process of work, regarding risks of exposing themselves to the etiological agent and, indirectly, their family members and other contacts ${ }^{(25)}$. Also, risks include long shifts, psychological suffering, tiredness, professional Burnout, stigma, and physical and psychologic violence ${ }^{(26)}$. In work environment, the physical load becomes dangerous when there is a psychophysical strain since work should be a generator of health and not of discomfort and pathology ${ }^{(12)}$.

The physical and mental fatigue, the need of using EPP continuously, and isolation of the family, added to anxiety to take difficult decisions during the work shift, become potential stressors factors in coping with COVID-19 pandemic ${ }^{(27)}$. For psychodynamics, there is no separation between the "inside job" and the "outside job," since the psychic functioning is not divisible, considering the family circle necessary to workers to keep their defenses and return to work ${ }^{(13)}$.

Despite the importance of the family circle to workers, as part of their defenses, they needed to be dissociated because of the high contagion and severity of COVID-19, with a new work process for practitioners. A study conducted by Avanian ${ }^{(28)}$ listed some factors that are contributing for psychological suffering of health professionals who directly assist patients with COVID-19: emotional effort and physic exhaustion in dealing with an increasing number of patients, take care of co-workers who may get severely ill and, sometimes, die of COVID-19, concerns about infecting family members, anxiety about taking on new or unknown clinical roles, and expanded workloads in caring for patients with COVID19. All these reports were taken from practitioners that participated in this survey.

For Dejours ${ }^{(13)}$, the intense and accelerated rhythm of work by the lack of practitioners, together with overcrowding, confirm an inadequacy between the present work process and the actual work organization, resulting in subjective mobility with feelings of anguish, stress, and fear, which contribute to suffering at work, as mentioned by the practitioners in the present study.

In other investigations, health professionals use to report increased symptoms of anxiety, depression, loss of sleep quality, and psychosomatic symptoms ${ }^{(29)}$. They also highlight implications about the mental health of the health professionals identified in the speech of the participants: the proximity to the suffering and death of patients associated with the anguish of family members, lack of medical resources, uncertain information about the conduction of care, loneliness, and worries with family members, resulting sometimes in an unwillingness to work ${ }^{(30)}$.

These consequences on mental health refer to defensive strategies, described by Dejours ${ }^{(14)}$ as mechanisms that workers seek to modify, transform, and minimize their perception of reality that make them suffer. It is an internal process of the individuals, since they cannot change the pressure imposed by the work organization ${ }^{(14)}$.

During pandemics, people's physical health and the fight against the infectious agent are the focus of attention for managers and health professionals, so that the repercussions on mental health tend to be neglected ${ }^{(31)}$. However, the measures taken to reduce the psychological implications of the pandemic cannot be overlooked ${ }^{(32)}$.

The lack of measures to deal with psychological issues propitiates negative results associated with the disease, mainly because such consequences may be more lasting and prevalent than the disease itself, impacting many sectors of the society ${ }^{(33)}$. Thus, it is crucial to ensure medical assistance and psychological support to the health professionals ${ }^{(5)}$.

Problems such as physical tiredness and psychological stress, failure and/or negligence related to the protection and health care measures of these practitioners do not affect the many categories, in the same way, confirming the need to give attention to specificities of each one to avoid the reduction of the work capacity and the quality of care provided to patients ${ }^{(29)}$.

Thus, Dejours ${ }^{(19)}$ highlights the importance of teamwork among all hierarchical levels, aiming to develop cooperative labor and everyone's commitment, which makes possible a subjective 
experience (of the team members) with collective consequences. It is possible because such teamwork allows elaborating favorable conditions to master the feeling and change it into creativeness, searching for strategies for coping that aims recognition and identification, so that suffering makes sense and pleasure is the result of this adverse situation ${ }^{(19)}$.

Practitioners emphasized the lack of awareness of the population to avoid the COVID-19 dissemination in their daily practices as an adverse situation from the outside environment for their daily work. However, the modification of the behavior depends on the context, and it is difficult to predict due to social characteristics, socioeconomic and behavioral differences between populations ${ }^{(34)}$. Brazil has little experience with disasters and calamities, and there is not a local prevention culture ${ }^{(34)}$.

Therefore, a need arises for work organizations to provide individual and collective coping strategies: individual coping occurs without the physical presence of the causative agent of suffering since it is internalized (psychic). The collective depends on the presence of external conditions and is kept in the consensus of the working group ${ }^{(14)}$.

In this study, we observed, as an innovative factor, the identification of coping strategies that generate motivation and satisfaction to practitioners regarding the care provided to patients with COVID-19, such as help people with quality care and realize the recovery and discharge of patients. These two aspects can drive them to keep working, a fact not identified in scientific literature, since it describe only the physical and psychological stressors experienced by the health professionals. We highlight that the study was developed under the practitioner's view who work in the many Brazilian States, and we observed their satisfaction, even in regions with inequality in the availability of health equipment and supplies as well as great cultural diversity and unequal economic distribution ${ }^{(23)}$.

The level of job satisfaction is an essential subjective evaluation and has a direct relationship with the representation that workers have about the importance of their job, indicating that the daily suffering subjectively mobilizes the practitioners ${ }^{(35)}$.

Subjective mobilization issues are essential for the individuals to find meaning at work, to feel they are fulfilled again, and establish rich relationships, that is why the work psychodynamic dedicates to analyze the dynamic of psychic processes involved in confronting the individual with the work reality ${ }^{(12)}$.

In this study, this labor sense was shown by the practitioners when they express motivation and satisfaction in promoting safety, care, pain and suffering reliefs, save, and win the war, even before so many difficulties and obstacles inherent to their actuation.

When the worker finds a labor sense to transform the suffering situations into pleasure, adverse situations in the work environment cease to be destabilizing elements and start to develop a role in strengthening workers' identity and increasing their resilience, becoming coping strategies, and change of the situations ${ }^{(19)}$.

The analysis of how the work environments are organized is decisive for disease prevention. In this sense, the understanding of how different occupational groups are exposed to infections and diseases at the workplace may help in the response and the risk management related to COVID-19 by the public health, and subsequent outbreaks of other infectious diseases ${ }^{(26)}$.
Despite protection measures, training, and offer of appropriate work conditions to health professionals from health units are needed, it is important that we, above all, allocate more resources for such measures, hiring a greater number of practitioners on the frontline, considerations, and actions that focus on the organization of work processes, approaching management responsible for the work environments and training of workers ${ }^{(23)}$.

Regarding risks, we observe misunderstandings about exposure to the risks of suffering occupational injuries, making them natural in some activities as they were acceptable so that the health of the worker starts to be analyzed in a completely separate way from the work conditions ${ }^{(26)}$. However, we know that the safety of health workers is essential for them to offer the best professional services ${ }^{(36)}$.

\section{Study limitations}

The study presented limitations, since it confirmed the perception of active health professionals, almost in its totality, in the hospital environment, however, the health assistance was modified in all levels of attention, which prevents the more comprehensive generalization of findings. Thus, we recommend the development of studies in other areas such as Primary Health Care and pre-hospital service to understand the reality and perception of those practitioners.

\section{Considerations to health area}

The study confirms that, during the coping of emergencies of public health, it is possible to establish strategies that contribute to the restructuration of care practices in health services, and aim to organize the work processes, so that combating the infectious agent and physical health are not the only focus of attention for managers.

\section{FINAL CONSIDERATIONS}

This study results allowed to discuss the difficulties, impressions, feelings, and coping strategies during the assistance provided in the pandemic period of the COVID-19 from the perspective of health professionals, mentioned in television media.

In this perspective, practitioners show subjective mobility when they face the overload, which culminates in feelings of exhaustion, fear, sadness, and also physical and emotional tiredness. However, they describe worry in establishing a confident relationship with patients and family members, ensuring humanized and sensitive care, intending to promote recovery and possible discharge, goals constituted as coping strategies that generate motivation and satisfaction to the practitioners in their workplace.

Thus, this study brings a reflection on the worker's health, mainly about the need to allocate resources to this area to guarantee actions that focus on the organization and restructuration of the work process, to avoid or soften the physical and psychic overload in situations of public calamities, such as that of COVID-19. In fact, the pandemic only exposed an already fragile scenario of public health, which is continuously experienced by health professionals. 


\section{REFERENCES}

1. Cheng ZJ, Shan J. 2019 Novel coronavirus: where we are and what we know. Infection. 2020;48:155-63. https://doi.org/10.1007/s15010-020-01401-y

2. World Health Organization (WHO). Novel coronavirus China: disease outbreak news [Internet]. 2020 [cited 2020 Oct 12]. Available from: https://www.who.int/csr/don/12-january-2020-novel-coronavirus-china/en/

3. World Health Organization (WHO). Rolling update son coronavirus disease [Internet]. 2020 [cited 2020 Oct 15]. Available from: https://www. who.int/emergencies/diseases/novel-coronavirus-2019/events-as-they-happen

4. Ministério da Saúde (BR). Secretaria de Vigilância em Saúde. Boletim epidemiológico especial: Semana Epidemiológica 39 (20 a 26/09). Doença pelo coronavírus COVID-19 [Internet]. 2020 [cited 2020 Oct 20]. Available from: https://www.gov.br/saude/pt-br/media/pdf/2020/ dezembro/03/boletim_epidemiologico_covid_39.pdf

5. Medeiros EA. Health professionals fight against COVID-19. Acta Paul Enferm. 2020;33:e-EDT20200003. https://doi.org/10.37689/ acta-ape/2020EDT0003

6. Gallasch CH, Cunha ML, Pereira LAS, Silva-Jr JS. Prevention related to occupational exposure: COVID-19. Rev Enferm UERJ. 2020;28:e49596. https://doi.org/10.12957/reuerj.2020.49596

7. Organização Mundial da Saúde (OMS). Cerca de 570 mil profissionais de saúde se infectaram e 2,5 mil morreram por COVID-19 nas Américas. Banco de Notícias. OPAS/OMS BRASIL [Internet]. 2020 [cited 2020 Oct 13]. Available from: https://www.paho.org/bra/index.php?option=com_cont ent\&view=article\&id=6270:cerca-de-570-mil-profissionais-de-saude-se-infectaram-e-2-5-mil-morreram-por-covid-19-nas-americas\&ltemid=812

8. Bezerra ACV, Silva CEM, Soares FRG, Silva JAM. Factors associated with people's behavior in social isolation during the COVID-19 pandemic. Ciênc Saúde Coletiva. 2020;25(Supl.1):2411-21. https://doi.org/10.1590/1413-81232020256.1.10792020

9. Sousa Jr JH, Raasch M, Soares JC, Ribeiro LVHAS. Da Desinformação ao Caos: uma análise das Fake News frente à pandemia do Coronavírus (COVID-19) no Brasil. Cad Prospec. 2020;13(2):331-46. https://doi.org/10.9771/cp.v13i2.COVID-19.35978

10. Soares SSS, Carvalho EC, Varella TCMML, Andrade KBS, Souza TDO, Souza NVDO. Brazilian nursing in the fight against the infodemic during the COVID-19 pandemic. Cogitare Enferm. 2020;25:e74676. https://doi.org/10.5380/ce.v25i0.74676

11. COVID-19: protecting health-care workers [Editorial]. Lancet. 2020;395(10228):922. https://doi.org/10.1016/S0140-6736(20)30644-9

12. Dejours C. Subjetividade, trabalho e ação. Rev Produç [Internet]. 2004 [cited 2020 Aug 15];14(3):27-34. Available from: https://www.scielo. $\mathrm{br} / \mathrm{pdf} / \mathrm{prod} / \mathrm{v} 14 \mathrm{n} 3 / \mathrm{v} 14 \mathrm{n} 3 \mathrm{a} 03 . \mathrm{pdf}$

13. Dejours C. Trabalho e saúde mental: da pesquisa à ação. In: Dejours C, Abdoucheli E, Jayet C. Psicodinâmica do trabalho: contribuições da escola dejouriana à análise da relação prazer, sofrimento e trabalho. São Paulo: Atlas; 1994. p. 21-32.

14. Dejours C. A carga psíquica do trabalho. In: Dejours C, Abdoucheli E, Jayet C. Psicodinâmica do trabalho: contribuições da escola dejouriana à análise da relação prazer, sofrimento e trabalho. São Paulo: Atlas; 1994. p. 45-65.

15. Borba F. Measuring Negative Campaigning on TV, radio, debates, press and Facebook: the case of 2014 Brazilian Presidential Elections. Intercom, Rev Bras Ciênc Comum. 2019;42(1):37-56. https://doi.org/10.1590/1809-5844201912

16. Souza MAR, Wall ML, Thuler ACMC, Lowen IMV, Peres AM. The use of IRAMUTEQ software for data analysis in qualitative research. Rev Esc Enferm USP. 2018;52:e03353. https://doi.org/10.1590/S1980-220X2017015003353

17. Soares PR, Silva CRL, Louro TQ. Comfort the child in intensive pediatric therapy: perception of nursing professionals. Rev Bras Enferm. 2020;73(4):e20180922. https://doi.org/10.1590/0034-7167-2018-0922

18. Bardin L. Análise de conteúdo. São Paulo: Edições 70; 7a ed., terceira parte. 2011. p.123-187.

19. Dejours C. Uma nova visão do sofrimento humano nas organizações. In: Chanlat, JT. O indivíduo na organização: dimensões esquecidas. São Paulo: Atlas; 1993. p. 320.

20. Ferguson NM, Laydon D, Gemma NG. Impact of non-pharmaceutical interventions (NPIs) to reduce COVID-19 mortality and health care demand. Imperial College London. 2020. https://doi.org/10.25561/77482

21. Duan L, Zhu G. Psychological interventions for people affected by the COVID-19 epidemic. Lancet Psychiatr. 2020;7(4):300-2. https://doi. org/10.1016/S2215-0366(20)30073-0

22. Cabral ERM, Melo MC, Cesar ID, Oliveira REM, Bastos TF, Machado LO, Rolim ACA, Zago ACW. Contributions and challenges of the Primary Health Care across the pandemic COVID-19. InterAm J Med Health. 2020;3:e202003012. https://doi.org/10.31005/iajmh.v3i0.87

23. Barroso BIL, Souza MBCA, Bregalda MM, Lancman S, Costa VBB. Worker health in COVID-19 times: reflections on health, safety, and occupational therapy. Cad Bras Ter Ocup. 2020;28(3):1093-102. https://doi.org/10.4322/2526-8910.ctoARF2091

24. Sant'ana G, Imoto AM, Amorim FF, Taminato M, Peccin MS, Santana LA, et al. Infection and death in healthcare workers due to COVID-19: a systematic review. Acta Paul Enferm. 2020;33:1-9. https://doi.org/10.37689/acta-ape/2020AO0107

25. Duarte MMS. Description of COVID-19 hospitalized health worker cases in the first nine weeks of the pandemic, Brazil, 2020. Epidemiol Serv Saude. 2020;29(5):e2020277. https://doi.org/10.1590/S1679-49742020000500011 
26. Silva LS, Machado EL, Oliveira HN, Ribeiro AP. Condições de trabalho e falta de informações sobre o impacto da COVID-19 entre trabalhadores da saúde. Rev Bras Saúde Ocup. 2020;45:e24. https://doi.org/10.1590/2317-6369000014520

27. Dal'bosco EB, Floriano LSM, Skupien SV, Arcaro G, Martins AR, Anselmo ACC. Mental health of nursing incoping with COVID-19 at a regional university hospital. Rev Bras Enferm. 2020;73(Suppl 2):e20200434. https://doi.org/10.1590/0034-7167-2020-0434

28. Avanian JZ. Mental health needs of health care workers providing front line COVID-19 care: editor's comment. JAMA [Internet]. 2020 [cited 2020 Oct 13]. Available from: https://jamanetwork.com/channels/health-forum/fullarticle/2764228.

29. Teixeira CFS, Soares CM, Souza EA, Lisboa ES, Pinto ICM, Andrade LR, et al. The health of healthcare professionals coping with the COVID-19 pandemic. Ciênc Saúde Coletiva. 2020;25(9):3465-74. https://doi.org/10.1590/1413-81232020259.19562020

30. Huang L, Lin G, Tang L, Yu L, Zhou Z. Special attention to nurses' protection during the COVID-19 epidemic. Critical Care. 2020;24:120. https://doi.org/10.1186/s13054-020-2841-7

31. Schmidt B, Crepaldi MA, Bolze DAS, Neiva Silva L, Demenech LM. Saúde mental e intervenções psicológicas diante da pandemia do novo coronavírus (COVID-19). Estud Psicol (Campinas). 2020;37:e200063. https://doi.org/10.1590/1982-0 275202037e200063

32. Xiao C. A Novel Approach of Consultation on 2019 Novel Coronavirus (COVID-19) - Related Psychological and Mental Problems: structured letter therapy. Psychiatry Investig. 2020;17(2):175-6. https://doi.org/10.30773/pi.2020.0047

33. Ornell F, Schuch JB, Sordi AO, Kessler FHP. "Pandemic fear" and COVID-19: mental health burden and strategies. Braz J Psychiatry. 2020;42:232-5. https://doi.org/10.1590/1516-4446-2020-0008

34. Lima DLF, Dias AA, Rabelo RS, Cruz ID, Costa SC, Nigri FMN, et al. Covid-19 in the State of Ceará: behaviors and beliefs in the arrival of the pandemic. Ciênc Saúde Coletiva. 2020;25(5):1575-86. https://doi.org/10.1590/1413-81232020255.07192020

35. Teixeira FD, Prebianchi HB. Comprometimento, estresse e satisfação com a vida de profissionais da saúde. Rev Psicol, Organ Trab. 2019;19(2):598-606. https://doi.org/10.17652/rpot/2019.2.15321

36. Huh S. How to train health personnel to protect themselves from SARS-CoV-2 (Novel Coronavirus) infection when caring for a patient or suspected case. J Educ Eval Health Prof. 2020;17:10. https://doi.org/10.3352/jeehp.2020.17.10 